\title{
EVALUATING CARBONATE DISSOLUTION AND PRECIPITATION IN A SHORT TIME-FRAME USING SEM: TECHNIQUES AND PRELIMINARY RESULTS FROM POSTOJNA CAVE, SLOVENIA
}

\author{
OCENA KRATKOTRAJNEGA RAZTAPLJANJA IN IZLOČANJA \\ KARBONATA Z UPORABO VRSTIČNEGA ELEKTRONSKEGA \\ MIKROSKOPA: METODOLOŠKI POSTOPKI IN PRELIMINARNI \\ REZULTATI IZ POSTOJNSKE JAME
}

\author{
Vanessa E. JOHNSTON ${ }^{1,2^{*}}$, Adrijan KOŠIR ${ }^{2} \&$ Andrea MARTÍN-PÉREZ ${ }^{2}$
}

\begin{abstract}
UDC 544.351:552.541(497.471)
Vanessa E. Johnston, Adrijan Košir \& Andrea Martín-Pérez: Evaluating carbonate dissolution and precipitation in a short time-frame using SEM: techniques and preliminary results from Postojna Cave, Slovenia

Carbonate dissolution and precipitation are important geological processes whose rates often require quantification. In natural settings, these processes may be taking place at a slow rate, and thus, it may not be easily visible which of these processes is occurring. Alternatively, if the effects of precipitation/dissolution are visible, it may not be clear if they are still underway or an artefact of past conditions. Moreover, these two opposing processes may flip states depending on the environmental conditions, such as, on a seasonal basis. Here, we present the technical details and preliminary results of a method using carbonate tablets and Scanning Electron Microscopy (SEM) to evaluate which process (carbonate dissolution or precipitation) is occurring, using as an example, a cave environment. Our method involves making tablets by encasing blocks of carbonate rock into resin and polishing these to form a completely flat and smooth "zero surface". These tablets are observed under SEM in exactly the same points both before and after exposure to the field environment, using a system of marking lines at specific locations on the resin. Our results show significant differences in the before and after images of the tablet surface after just six weeks in the cave. Furthermore, the use of the insoluble resin zero surface permits a comparison of the starting height with the new dissolved/precipitated surface that can be used to quantitatively estimate the rate of dissolution/precipitation
\end{abstract}

\begin{abstract}
Izvleček
UDK 544.351:552.541(497.471)

Vanessa E. Johnston, Adrijan Košir \& Andrea Martín-Pérez: Ocena kratkotrajnega raztapljanja in izločanja karbonata $z$ uporabo vrstičnega elektronskega mikroskopa: metodološki postopki in preliminarni rezultati iz Postojnske jame

Raztapljanje in izločanje karbonatnih mineralov spadata med geološke procese, katerih hitrost pogosto želimo kvantitativno ovrednotiti. V naravnih okoljih so ti procesi počasni, zato običajno ni enostavno oceniti, kateri proces trenutno poteka na določeni točki, niti tega, ali so vidni učinki raztapljanja ali izločanja posledica aktivnih pogojev in procesov ali dogajanj v preteklosti. Poleg tega se nasprotujoča si procesa lahko hitro izmenjujeta zaradi sprememb v jamskem okolju, na primer sezonsko. V članku prikazujemo metodologijo in preliminarne rezultate preiskave apnenčevih ploščic (tablet), izpostavljenih pogojem raztapljanja in/ali izločanja $\mathrm{v}$ jamskem okolju, pod vrstičnim elektronskim mikroskopom (SEM). Metodologija obsega izdelavo testnih ploščic iz apnenca, ki smo jih zalili v epoksidno smolo, izravnali in spolirali do ravne in gladke referenčne površine. Preden smo jih izpostavili naravnim pogojem, smo ploščice označili z referenčnimi lokacijskimi točkami na meji med smolnim obodom in kamnino ter referenčna področja fotografirali pod SEM v grobovakuumskih pogojih. Nadaljne analize z SEM so pokazale znatne razlike na površini ploščic že po šestih tednih izpostavljenosti jamskim pogojem: s primerjavo z nivojem netopne epoksidne smole smo lahko neposredno ugotovili, ali je na apnenčevi ploščici prišlo do raztapljanja ali do izločanja. Referenčna mejna področja na ploščicah smo nato pod SEM analizirali v tedenskih in mesečnih intervalih
\end{abstract}

\footnotetext{
${ }^{1}$ Research Centre of the Slovenian Academy of Sciences and Arts, Karst Research Institute, Titov trg 2, SI-6230 Postojna, Slovenia

${ }^{2}$ Research Centre of the Slovenian Academy of Sciences and Arts, Institute of Palaeontology, Novi trg 2, SI-1000 Ljubljana,

Slovenia, e-mails: vanessa.johnston@zrc-sazu.si, adrijan.kosir@zrc-sazu.si, andrea.martin-perez@zrc-sazu.si

* Corresponding author
}

Received/Prejeto: 12. 3.2021

DOI: https://doi.org/10.3986/ac.v50i2-3.9788 
happening at a field location in a relatively short time-frame (weeks/months). This method could be used in numerous natural and industrial settings to identify these processes that can be caused purely geochemically, but also through microbialmediation and physical weathering.

Keywords: rock tablets, carbonate dissolution, SEM, 3D microtopography, caves, karst.
Z uporabo stereoskopske topografske rekonstrukcije, s katero smo kvantitativno ocenili hitrost raztapljanja oziroma izločanja karbonata. Metoda je potencialno uporabna za proučevanje geokemijskih, mikrobno induciranih in mehanskih prosesov na mikroskopski ravni v naravnih in laboratorijskih (industrijskih) pogojih.

Ključne besede: kamninske ploščice, raztapljanje karbonata, vrstični elektronski mikroskop, 3D mikrotopografija, jame, kras.

\section{INTRODUCTION}

The study of carbonate geomorphology often requires an understanding or quantification of the rates of carbonate precipitation and/or dissolution (Moses et al., 2014; Goudie, 2016). Such analysis is useful in many different contexts, such as, the study of surface weathering and erosion, dissolution and precipitation in rivers and in the sea, building conservation, engineering applications and slope stability, cave formation and the growth or destruction of speleothems, industrial processes and construction materials, and for the preservation of cultural artefacts. Furthermore, the interaction of microorganisms with carbonate rocks is becoming more apparent as an important mechanism for calcite precipitation and dissolution, both actively and passively, with important industrial applications (De Muynck et al., 2010).

In natural settings, the rate of carbonate dissolution cannot be evaluated by the rates determined in laboratory experiments, since factors, such as mechanical erosion, biological activity and water flow, exhibit a large influence on the dissolution process (Levenson et al., 2017). Traditionally, rates of carbonate dissolution have been measured using micro-erosion meters attached to the rock surface (e.g., High \& Hanna, 1970; Trudgill et al., 1981; Häuselmann, 2008; Furlani et al., 2009; Stephenson and Finlayson, 2009) or carbonate erosional weightloss pills/tablets placed in the area of interest (e.g., Gams, 1981; Plan, 2005; Prelovšek, 2009; Covington et al., 2013; Krklec et al., 2021). Unfortunately, such analyses require long time periods (often several months to years) of exposure to the natural environment to gain meaningful and accurate results (Moses et al., 2014). Moreover, errors may occur with the before and after weighing method since humidity in the air rapidly adds significant mass during the weighing process (Krklec et al., 2021), which needs to be quantified and corrected for in the resulting mass loss during exposure (Prelovšek, 2009).

A different approach involves geochemical analyses of carbonate waters to quantify the total solute load of waters deriving from the catchment area to calculate the total loss of carbonates (Gunn, 1981). However, such analyses often over-estimate the surface denudation because only around a third of the dissolution occurs on the exposed surface, while the majority happens in the subsurface fracture system (Gabrovšek, 2009).

More recently, cosmogenic isotopes, such as ${ }^{36} \mathrm{Cl}$, have been used to estimate denudation rates (Stone et al., 1998; Xu et al., 2013). However, such methods only work over long time-scales of exposure (thousands of years). Furthermore, the method is based on cosmogenic isotopes formed when rock surfaces are exposed to cosmic radiation (Bierman \& Steig, 1996), which would not occur in the protected underground environment. Given that all these methods require long temporal or large spatial exposure, they are not suited to measure at a microscale or rapid processes, such as seasonal changes, or to gain results in a short time. Therefore, a novel method to identify and measure carbonate precipitation and dissolution rates is required.

We present a methodology for discerning if calcite dissolution or precipitation is occurring currently and offer a means to make a quantitative estimate of the erosion/precipitation rate for field settings. Here, as an example of the strength of our methodology, we investigate dissolutional features in Postojna Cave, Slovenia, which we hypothesise are currently forming and are attributed to the high and highly-variable concentrations of $\mathrm{CO}_{2}$ in the air of the particular cave chamber studied (Kukuljan et al., 2021a). Due to the strong seasonality of the cave air $\mathrm{CO}_{2}$ concentrations, we needed a method to evaluate modifications to the rock surfaces on short temporal scales and to quantify the rates of dissolution and/or precipitation processes. Since these calcite processes were to be studied in a short time-frame (seasonally, for weeks to months), we relied on analyses at high-resolution on a mineralogical scale. Our method uses polished carbonate rock tablets that are embedded in resin. Scanning Electron Microscope (SEM) imaging is performed before and after exposure to the field envi- 
ronment. Although we are not the first to use this idea (e.g., Fornos et al., 2011; Krklec et al., 2016; White et al., 2021), here, we outline the methods used to prepare the tablets and to locate the exact position on the tablet under the SEM, before and after the field experiment. We then explain a novel 3D-imaging method that we have used to make a quantitative estimate of the precipitation or dissolution rate, which we demonstrate can flip between states on seasonal scales at certain cave sites.

\section{METHODS}

\section{TABLET PREPARATION}

The aim of our method was to prepare tablets composed of both carbonate and an insoluble reference material. These two materials would be flattened to form a uniform "zero surface" from which carbonate dissolution or precipitation could be distinguished and quantified with respect to the insoluble material. We propose the use of a fine grained, homogeneous limestone to avoid possible over-estimation of dissolution that may occur when large crystals or fossils within a heterogeneous rock fall out when a more soluble matrix dissolves around such features. Here, our chosen limestone is known under the commercial name "Dinarit" (Cretaceous, Central Dalmatia) and only the massive mudstone parts were selected (Johnston et al., 2021). The rock was cut into cuboids of approximately $20 \times 20 \times 5 \mathrm{~mm}$. Cuboids (two pieces per tablet) were placed in rectangular silicone rubber mounting cups (FlexiForm, Struers) and embedded under vacuum into an EPO-TEK 301 resin (Epoxy Technology, Inc.). The resin casts were cured for 2 hours at $65^{\circ} \mathrm{C}$, creating tablets with dimensions of $68 \times 37 \mathrm{~mm}$ and approximately $10 \mathrm{~mm}$ thick. Some of the tablets were cut to reduce the amount of resin on one margin (Figure 1). A small hole was drilled into the top of the tablet resin using a conventional drill to aid attachment to the field environment, such as, via a string, wire or stake. Since we were only interested in surface processes, within the mounting cup the resin also encased the upper side of the tablet, while the rock exposed on the lower surface (bottom of the mounting cup) was prepared for the analysis. The surfaces of these tablets to be used for analysis were lapped using a Logitech PM5 thin-section machine and 600 grit silicon carbide abrasive powder (mean grit size $25 \mu \mathrm{m}$ ). Lapped faces were then manually polished using a succession of silicon carbide pads (Kemet, UK) - P1200 (15 $\mu \mathrm{m}$ grit size), P2500 $(8 \mu \mathrm{m})$ and P4000 $(5 \mu \mathrm{m})$-to gain a smooth, uniform zero surface that was plane with the resin. To help locate the positions of the analyses, we made small marking lines at regular intervals on the resin, at the border between resin and the rock, using a diamond pencil (Figure 1A, B). A simple label was also
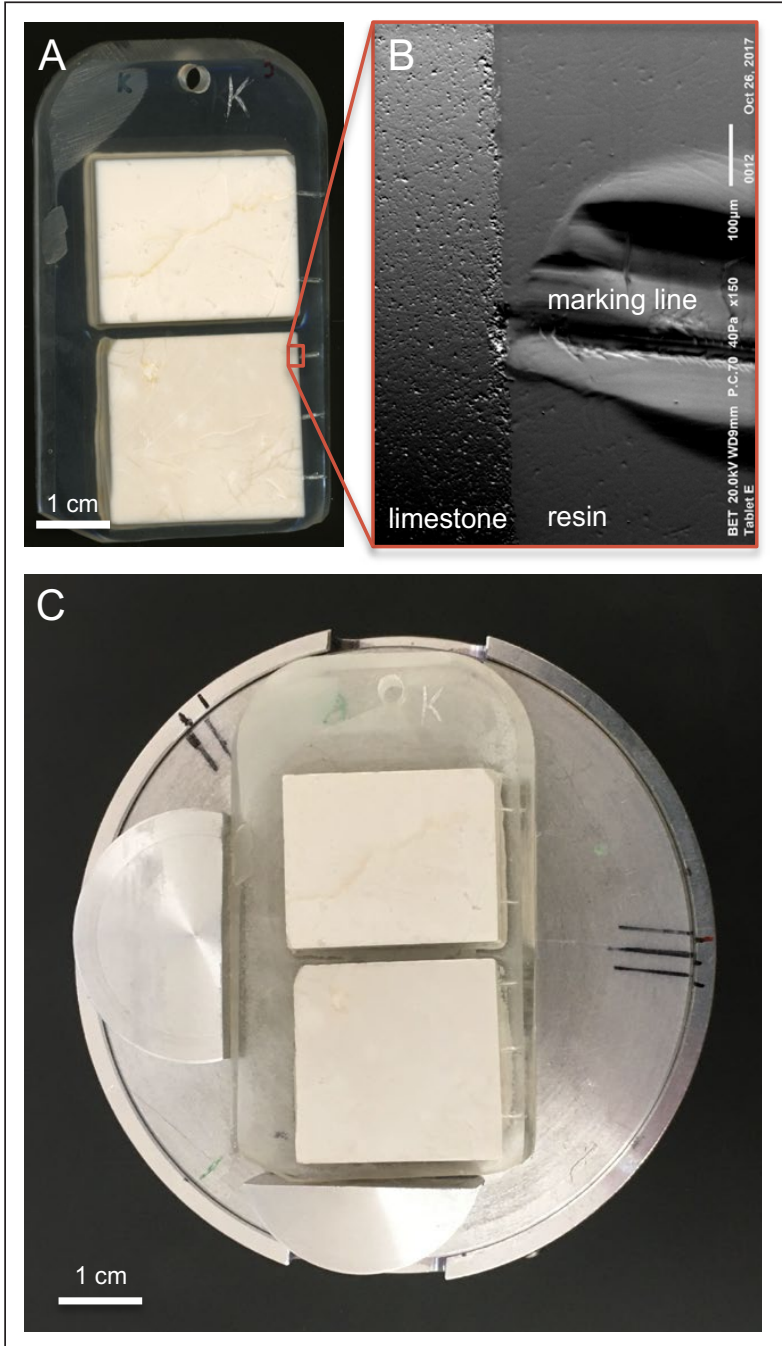

Figure 1: Images of a tablet and the adapted SEM holder. A) A flatbed scanner image of a selected tablet showing the calcite blocks set in resin, marking lines, labelling and fixing hole. Red square shows location of image B. B) BET SEM image of a marking line in the resin at the border between the resin and the calcite, used for locating the same point for the before and after images. C) Tablet $K$ mounted in the adapted SEM holder. The two semi-circular aluminium blocks permit the tablets to be mounted in the same position. 
engraved onto the top of each tablet in the resin using the same diamond pencil. The tablets were then ready for the first set of observations. All the tablets were scanned with a flatbed scanner to obtain images of the tablets before the experiments.

The tablets were observed under a JEOL JSM-IT100 SEM at the Laboratory of Microscopy, ZRC SAZU, Ljubljana. A special holder was created using two semicircular aluminium blocks glued at a right angle to a standard $75 \mathrm{~mm}$ diameter SEM holder, dedicated to the experiment. These blocks permitted the tablets to be mounted in the same position and at the same working distance for each analysis by aligning the sides and top of the tablets with the blocks (Figure 1C). The tablets were not coated with a conductive layer, allowing the possibility for them to be placed in the field successively, to observe ongoing processes. The analyses were carried out using a backscattered electron (BSE) detector under low vacuum conditions (35-40 $\mathrm{Pa}$ ), at an accelerating voltage of 15 or $20 \mathrm{kV}$, and a working distance between 9 and $11 \mathrm{~mm}$. Images were taken in topographic and shadow backscattered electron imaging modes ('BET' and 'BES' labels on photomicrographs), and complementary, in secondary electron imaging mode using a low-vacuum SE detector (LV SED). The tablets were first observed before exposure to the field to provide "before" images of the zero surface that would be used for comparison with the images gained, in the exact same location, after the field experiment.

\section{SITE SETTING}

Following the first set of "before" images, the tablets were placed in the terminal chamber (the Red Hall; Rdeča Dvorana "RD") of the Pisani rov passage of Postojna Cave (Postojnska jama, cave entrance: $45^{\circ} 46^{\prime} 52.5^{\prime \prime} \mathrm{N}$, $14^{\circ} 12^{\prime} 20.5^{\prime \prime E}, 529 \mathrm{~m}$ a.s.l.), Slovenia (Figure 2). Within this chamber, there are many dissolution features that have formed as cylindrical "cup shapes" below drip points (Kukuljan et al., 2021b) in the journal Water. These are thought to be forming due to the $\mathrm{CO}_{2}$-rich atmospheric conditions in this particular location (Johnston et al., 2019; Kukuljan et al., 2021a). The aim of using the tablets

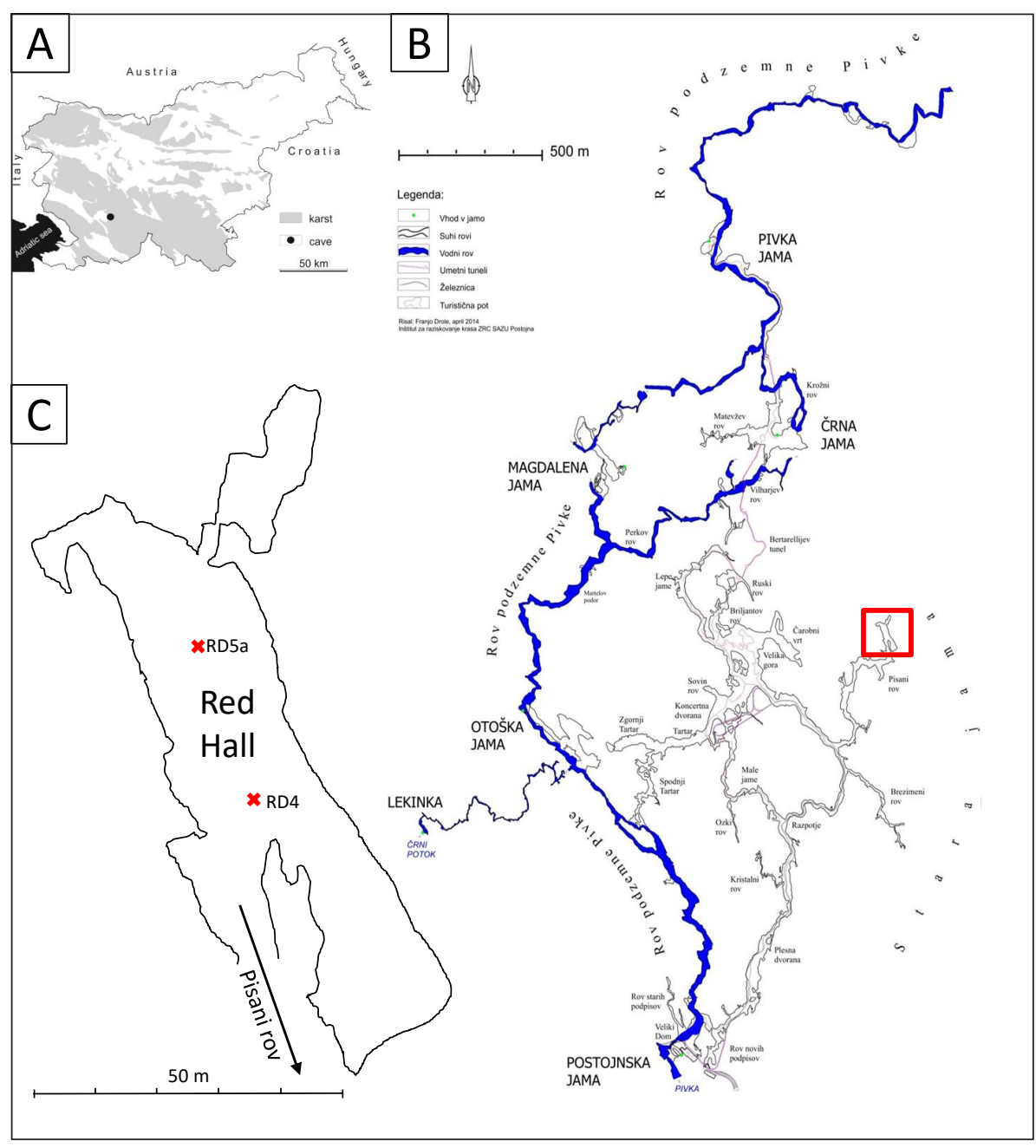

Figure 2: Map of the Postojna Cave sampling site. A) Map of Slovenia showing the location of the cave. B) Map of Postojna Cave. The red square indicates the terminal chamber of the Pisani rov passage (the Red Hall). C) Sketch of the Red Hall with the sampling points (RD4 and RD5a) marked as red crosses. Map A was created using Surfer 14 (Golden Software, https://www. goldensoftware.com/). Map B was drawn by Franjo Drole (2014) and $C$ was adapted from Luigi Gallino (1927), both found in the archive of the Karst Research Institute ZRC SAZU, Postojna. 
in this location was to assess whether these dissolution cups are still forming (currently dissolving) or if they are an ancient feature. Using this method, we are able to distinguish quickly (weeks) if dissolution or precipitation is occurring, while other methods (e.g., micro-erosion meters, weighing limestone pills) may take months/years to identify these processes conclusively. Furthermore, if dissolution is found, we outline a method to estimate the current rate of dissolution. We placed several tablets in the field for different amounts of time in different seasons within the cups, including 6 weeks and 20 weeks in winter, and 28 weeks in summer. As an example here, we show the results from tablets placed in two sites, RD4 and RD5a (Figure 3), in the Red Hall. RD4 is a large, white stalagmite with a fast drip rate, where the tablet was placed on the relatively flat stalagmite tip, directly below the drip point (Figure 3A). RD5 is a cylindrical corrosion cup with a slow, seasonal matrix flow drip rate that retains a pool of water throughout the year but with variable depth (Figure 3B).

The tablets were always transported in a watch glass, whereby the tablet was placed on the concave side of the watch glass with the experimental surface facing the glass. Given the shape of the tablet and watch glass, only the four corners of the tablet (resin part) would touch the glass, while the experimental surface is protected without anything touching it. The tablets were taped in place onto the watch glass and, both the watch glass and tablet together, were wrapped in plastic film and packaged in soft packing material within a box, and transported to the laboratory. On arrival, the tablets were unpacked and air-dried while still protected on the watch glass.

\section{SEM BEFORE AND AFTER IMAGING}

Tablets were observed under the SEM, 1) before exposure to the field environment and 2) after the field experiment, both in the exact same position to enable a better visualisation of the modifications to the rock surface. We started by locating the marking line on the rockresin contact at X150 magnification and saved an image. We then shifted a small, set distance inwards from the rock-resin contact using the coordination system in the software; in our case we chose $3 \mathrm{~mm}$. This was undertaken to avoid unwanted effects that may be caused at the edge of the rock cuboid and/or due to the presence of the resin. At which point, we took another image at x150 followed by various higher magnification images ( $x 500$ and $x 2000$ ) focused on the central point (i.e., not moving the stage). If there was a particular feature of interest within the wider field of view, its location could be marked on the lower magnification image before moving the stage, or alternatively moving using the software coordination system to move the small distance, the value of which would be noted down. We chose to use this approach entailing the resin marking lines rather than just using the software's coordinate system because any slight offset or rotation of the position of the tablet between that before the field and that after would compound over the distance across the $\sim 5 \mathrm{~cm}$-long tablet surface and may result in a relatively large error in the location on the $\mu \mathrm{m}$-scale. However, once the position of the marking line was located, a small shift (mm-scale) using the software was thought to have little compounding error and not cause too much offset from the original imaging location.
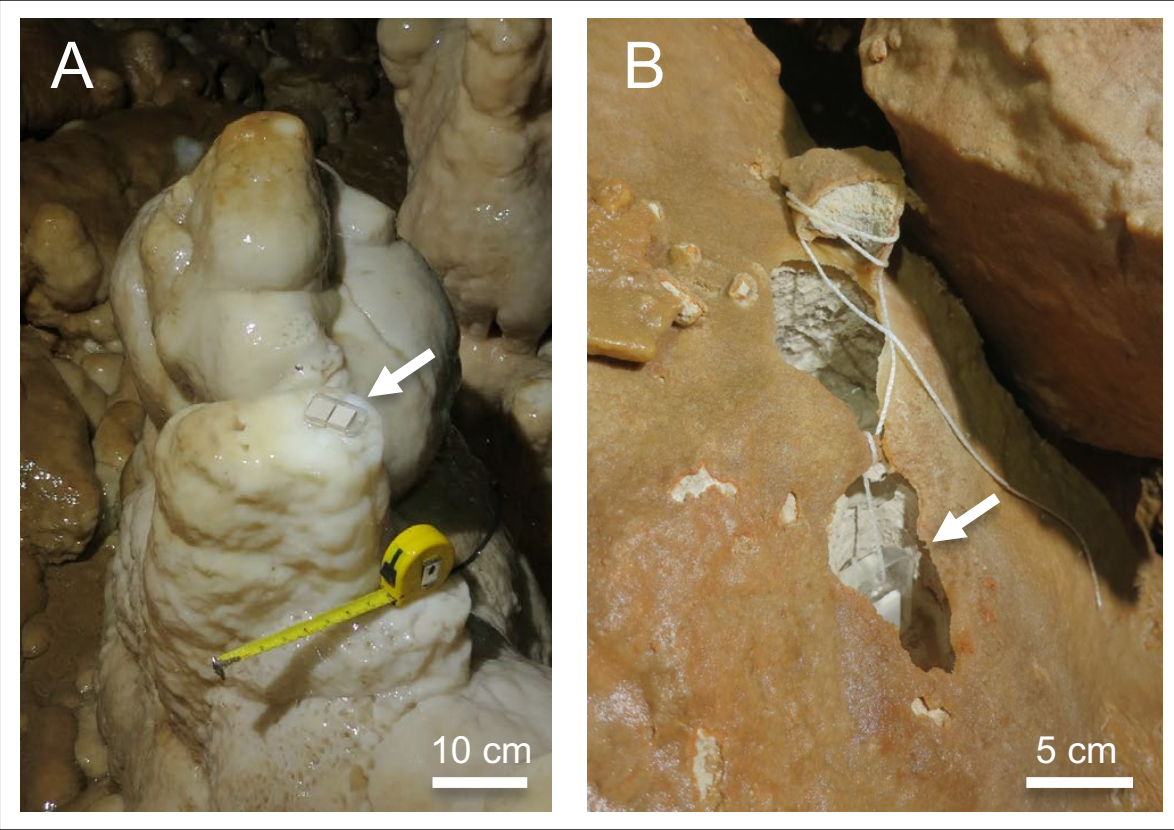

Figure 3: Cave sites used for the experiment. A) White stalagmite (RD4) with a relatively flat and wide top, which has formed under a fast flowing drip point. Tablet $K$ (arrow) was placed on the stalagmite tip, directly below the drip point. B) Cylindrical corrosion cup (RD5a) located below a slow, seasonal flow drip point that retains a pool of water throughout the year but with variable depth. Tablet $Q$ (arrow) was placed inside the cup and held in a vertical position using a string. 


\section{STEREOSCOPIC IMAGING AND 3D TOPOGRAPHIC ANALYSIS}

To gain a quantitative estimate of the amount of mineral precipitation or dissolution on the tablet after field exposure, we performed stereoscopic imaging and topographic reconstruction using the basic 3D Sight SEM software (ver. 1.26) linked to Smile View ${ }^{\text {mo }}$ visualisation interface (JEOL Co., Ltd.) of the microscope. This was carried out at the rock-resin interface, which permitted a comparison to be made between the resin height (initial zero surface) and the altered tablet surface, which could be lower (dissolution) or higher (precipitation) than the resin surface.

Stereopairs were obtained by taking an SEM image of the tablet at a defined magnification in an exactly horizontal position, followed by a "tilt" image of approximately the same area of the tablet taken after tilting the stage along a vertical axis by 5 degrees. The obtained original and tilt images for each stereopair were then manually aligned with a positional adjustment tool that specifies a small (easy-to-find) reference feature on both images using a mouse pointer. Precisely aligned image pairs and their stereo parameters, stored in separate files, were automatically used by the software to calculate 3D topographic (DEM) models of tablet surfaces at a real scale (Figure $4 \mathrm{~A}$ ). The 3D models were manually cropped to remove the topographic artefacts appearing on the margins due to the imperfect overlap of the stereopairs.

In the Tools/Profile menu, multiple height crosssections were produced from this $3 \mathrm{D}$ topographic model by manually specifying line segments (paths) on an image, crossing the resin-rock interface (an example of one of these paths is shown as the blue line in Figure 4B). Resulting cross-sections, displayed in dimensioned height/ path-length plots (Figure 4C), were used to measure the step height; namely, the difference between the resin level and a horizontal line, manually adjusted to fit the modified rock surface, to provide a quantitative value for the material gain/loss on the rock tablet (Figure 4D).

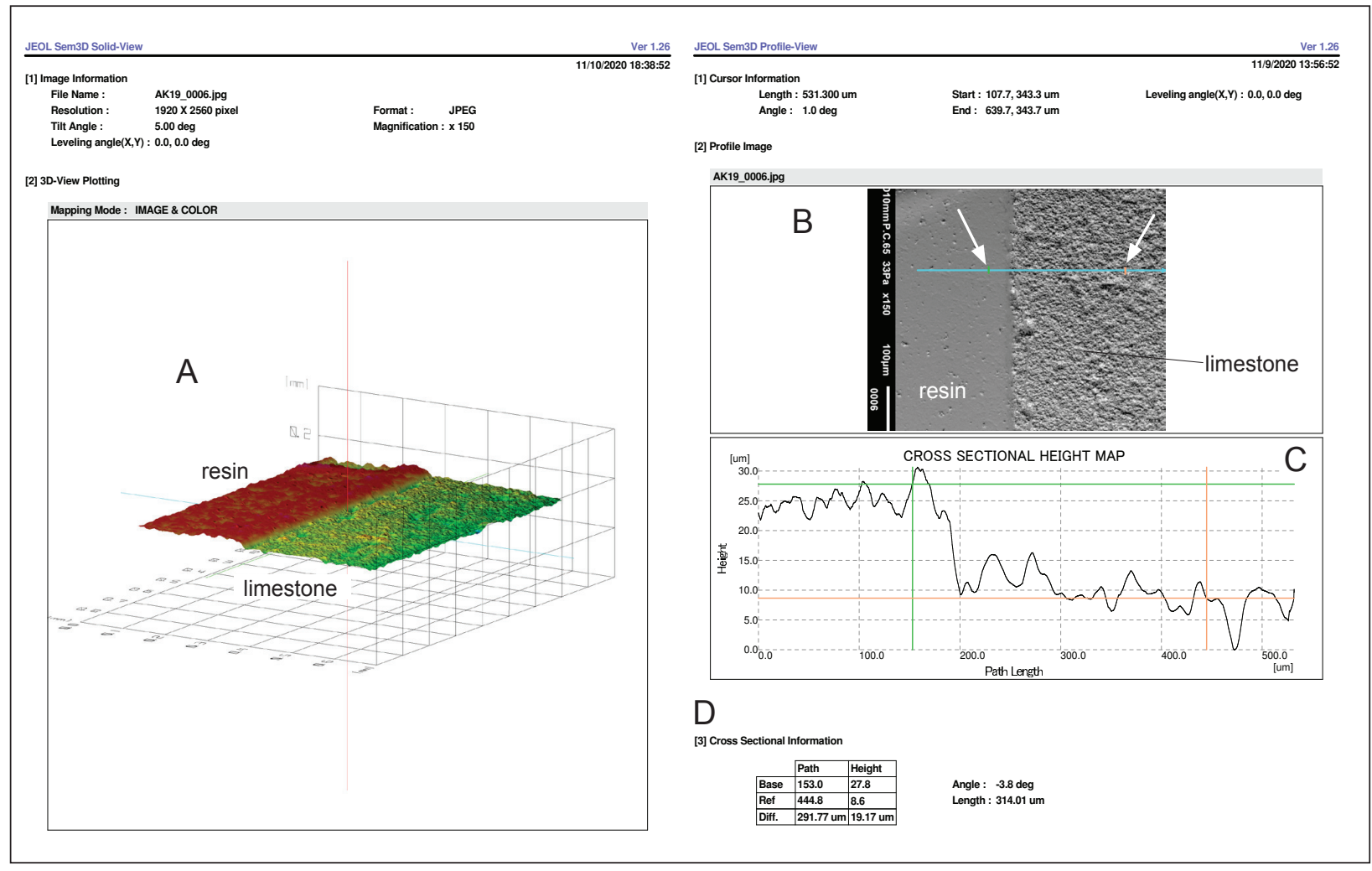

Figure 4: Report pages from the 3D Sight SEM software. A) Solid topographic model (DEM) generated from a stereoscopic image pair of the Tablet $Q$, using a combination of a grey-scale image and a coloured 3D topographic model. B) Part of an SEM image showing a manually defined profile line (blue) and C) a corresponding cross-section plot with real length and height dimensions ( $\mu m$ ). The two sets of horizontal and vertical line segments show the resin zero surface (green, called "base" by the software) and the modified rock surface (orange, called "reference" by the software). White arrows on the blue profile line (in B) indicate cursors corresponding to positions of vertical line segments in the cross-section view $(C)$ : sliding a vertical line segment along the topographic section raises or drops the level of a corresponding horizontal line segment. The difference in height between "base" (the resin zero surface) and "reference" (the modified rock texture) is simultaneously indicated in the cross sectional information table (D). 


\section{RESULTS}

We imaged the polished tablets before exposure to the cave environment. We found that the identification of the resin marking lines on the SEM was often better carried out using the topographical (BET) mode, while the images of the limestone surface were more successfully imaged using the shadow (BES) mode, which allowed the visualisation of individual crystals. LV SED images turned out to be less useful due to difficulties in reproducing similar brightness and contrast levels at different magnifications. Before field exposure, the surface of the limestone was shown to be flat and plane with the resin, successfully creating the zero surface. The calcite showed minor scratches caused by the polishing process. These scratches were randomly oriented but straight and not deep, and were easily identifiable as caused by the polishing. The original porosity of the rock was also visible (Figure 5A, C). The rock appeared homogeneous with the exception of a few areas characterised by larger crystals, often associated with recrystallized fossils and cemented porosity. Here, we show the results of tablets placed in two locations in the Red Hall of Postojna Cave; a corrosion cup (RD5a) and a stalagmite (RD4). For each of these two sites, we present data from both the winter and summer seasons.

\section{SITE 1: CORROSION CUP RD5A}

Two different tablets were placed in the Site 1 (RD5a) corrosion cup; “Tablet B" for six weeks in the winter
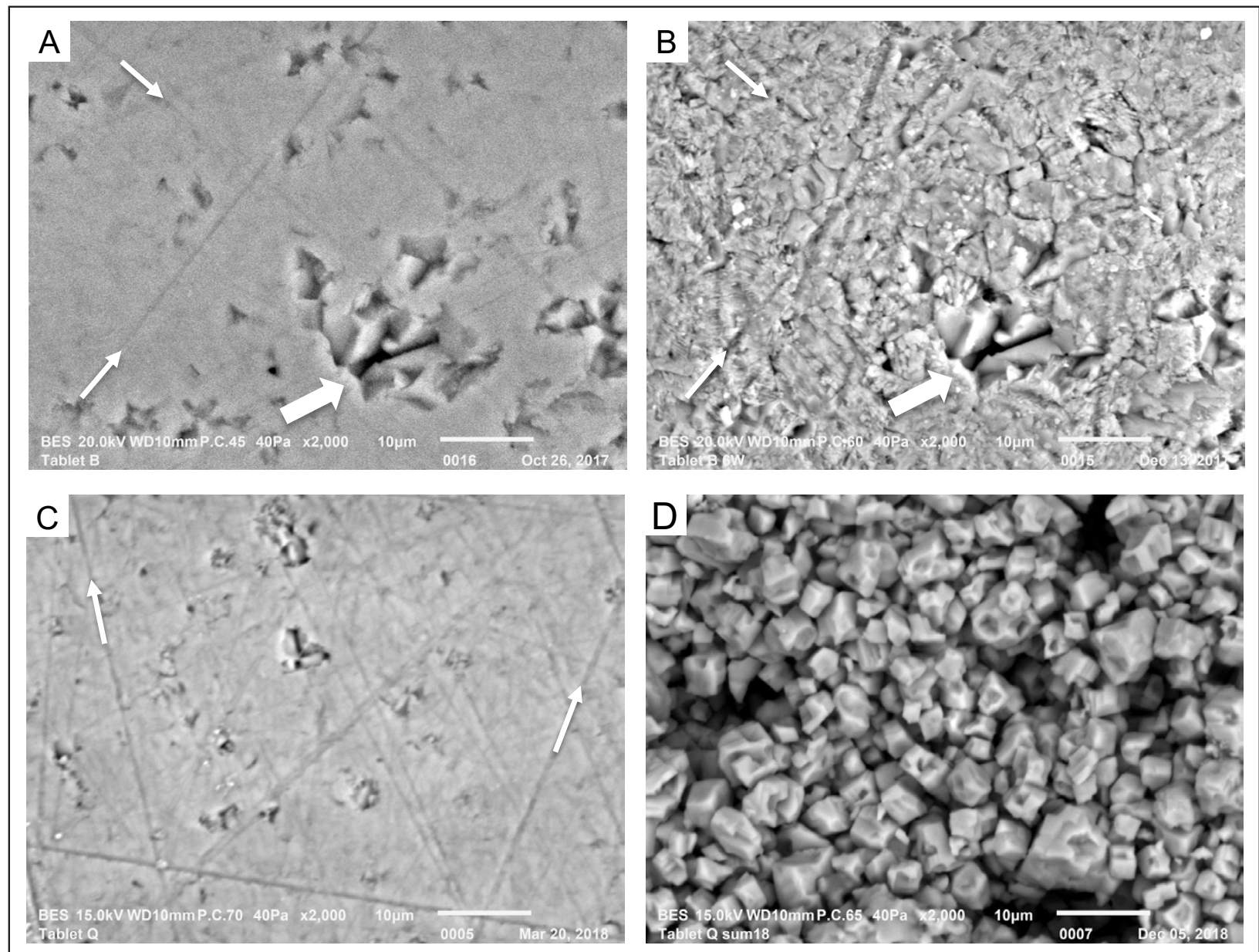

Figure 5: Before and after SEM images of two tablets from Site 1 (RD5a corrosion cup). A) Before and B) after images of Tablet B after six weeks in the cave during winter. It is clear that, using our method, the exact location of the "before" image has been found for the "after" image from the crystals evident in the pore space that are still recognisable after exposure to the field (wide white arrows) and some of the polishing scratches (narrow arrows). Dissolution has slightly modified the surface of the tablet, but this is considerable given that the tablet was in the cave for just six weeks in the winter (low cave air $\mathrm{CO}_{2}$ concentration). C) Before and D) after images of Tablet $Q$ after 28 weeks in the cave during summer (high cave air $\mathrm{CO}_{2}$ concentration). The surface of the tablet after field exposure has been significantly affected by dissolution resulting in a rough surface texture that exposes the individual crystals. Scale bars are $10 \mu m$. 
period (October 27 $7^{\text {th }}, 2017-$ December $6^{\text {th }}, 2017$ ) and "Tablet Q" for 28 weeks in the summer period (March $23^{\text {th }}, 2018$-October $29^{\text {th }}, 2018$ ). Before the experiment, Tablet B shows a flat surface with original porosity and polishing scratches (Figure 5A), typical of the zero surface observed on all tablets. After six weeks in winter, dissolution was already visible on Tablet B (Figure 5B). The dissolution was concentrated on the crystal margins and along the polishing scratches. Figure 5B clearly
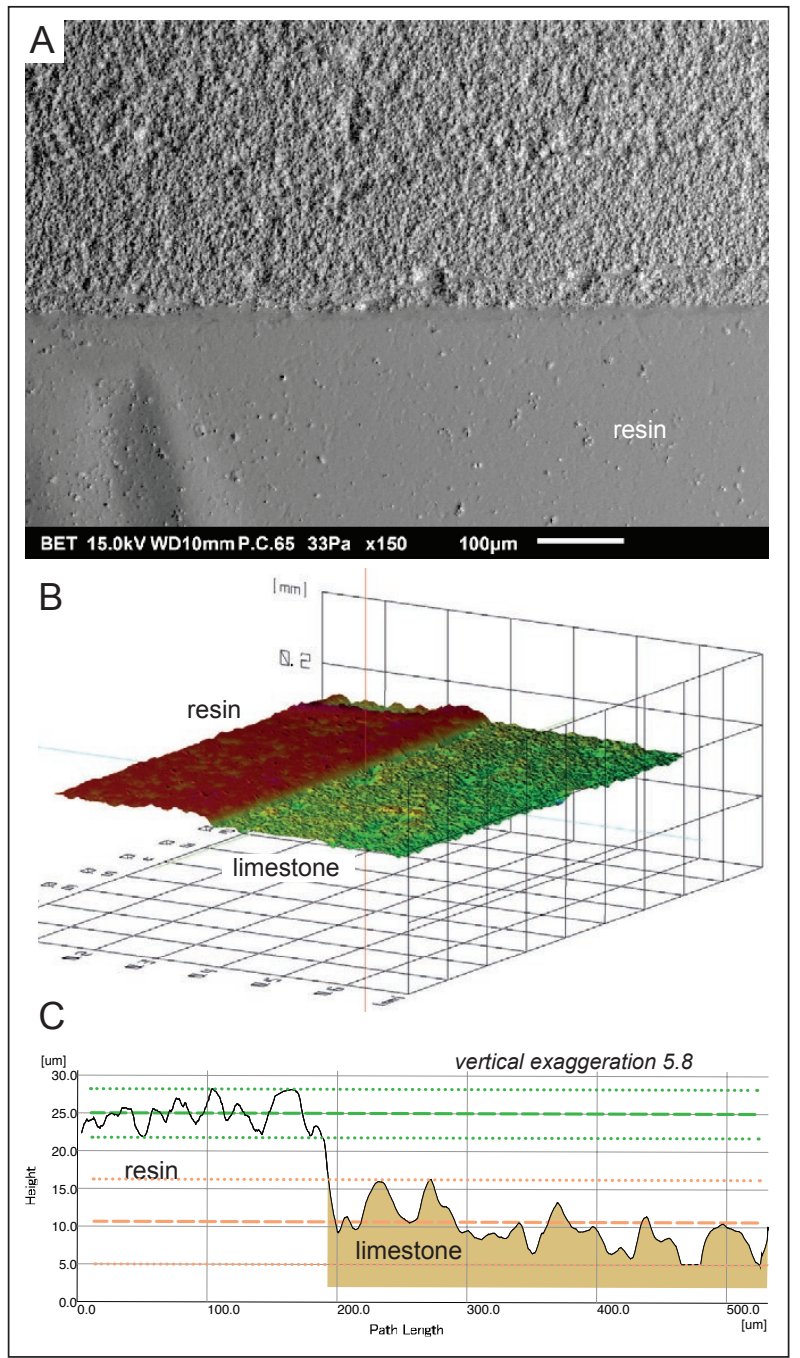

Figure 6: SEM image, 3D topographic model and cross-section used for quantitative analysis of limestone dissolution at Site 1 (RD5a corrosion cup). A) BET image of Tablet $Q$ after 28 weeks in the cave during summer showing the resin and the dissolved limestone. B) $3 D$ model of a selected area of the tablet showing the resin as a higher area (red) compared with the lower area (green to yellow colours) of the dissolved limestone surface. C) Cross-section through approximately $0.5 \mathrm{~mm}$-long segment over the resin-limestone border. Horizontal dotted lines mark minimum and maximum heights of the resin (green) and the limestone topography (orange), whereas dashed lines show mean topographic levels of the resin (green) and the limestone (orange). shows that the flat, rhombohedral crystal faces that form the large pore have not been modified while the polished surface is dissolved. The polishing scratches have been widened and deepened, and some appear to have become more pronounced, while others are no longer visible due to extensive dissolution. Despite the tablet only being exposed for six weeks in the cave, a considerable change to the tablet surface can be seen.

After 28 weeks in summer, significant dissolution had occurred. Tablet $\mathrm{Q}$ shows a completely different surface before and after the cave exposure. Before the field exposure, the tablet surface was, again, flat and smooth but with polishing scratches and original porosity visible (Figure 5C). After the field experiment, however, the flat surface is no longer visible at all (Figure 5D). Dissolution had occurred along the crystal margins over a considerable depth, exposing the individual, rhombohedral crystals, causing a rough surface texture. The polishing scratches have been completely obliterated and there is no resemblance to the tablet zero surface. This shows the importance of having before and after images in exactly the same location because one can be sure of the change that happened in that specific location. Furthermore, we show that relying on original features of the rock surface to relocate the position would not work when there has been strong dissolution, such as in Figure 5D.

To assess the amount of dissolution that had occurred, we studied areas of the tablet at the rock-resin interface (Figure 6A). Using the stereoscopic 3D technique, a significant lowering and roughening of the rock surface compared with that of the resin is shown (Figure 6B). After 28 weeks of cave exposure, the height difference, estimated by the step between the resin level and the average height of the dissolved limestone surface, was on the order of $10-25 \mu \mathrm{m}$. The dissolution value calculated from the mean levels in the cross-section shown in Figure $6 \mathrm{C}$ is approximately $14 \mu \mathrm{m}$ over 28 weeks in the summer season. Since the summer season, with highest cave air $\mathrm{CO}_{2}$ concentrations (Kukuljan et al., 2021a), has been shown to cause the greatest amount of dissolution (Kukuljan et al., 2021b), this dissolution value encompasses the majority of the total dissolution for the whole year. Therefore, this value would represent a minimum dissolution of $14 \mu \mathrm{m} \mathrm{yr}^{-1}$, which is consistent with typical rates of solutional denudation in karst (e.g., Ford \& Williams, 2007).

\section{SITE 2: STALAGMITE RD4}

Tablet $\mathrm{K}$ was placed on the top of the RD4 stalagmite for 20 weeks in the winter season (October 27 $7^{\text {th }}, 2017$-March $\left.15^{\text {th }}, 2018\right)$ and then removed for analysis. It was then placed back in the same position in the cave for another 28 weeks over summer (March $23^{\text {th }}, 2018-O c t o b e r 29^{\text {th }}$, 


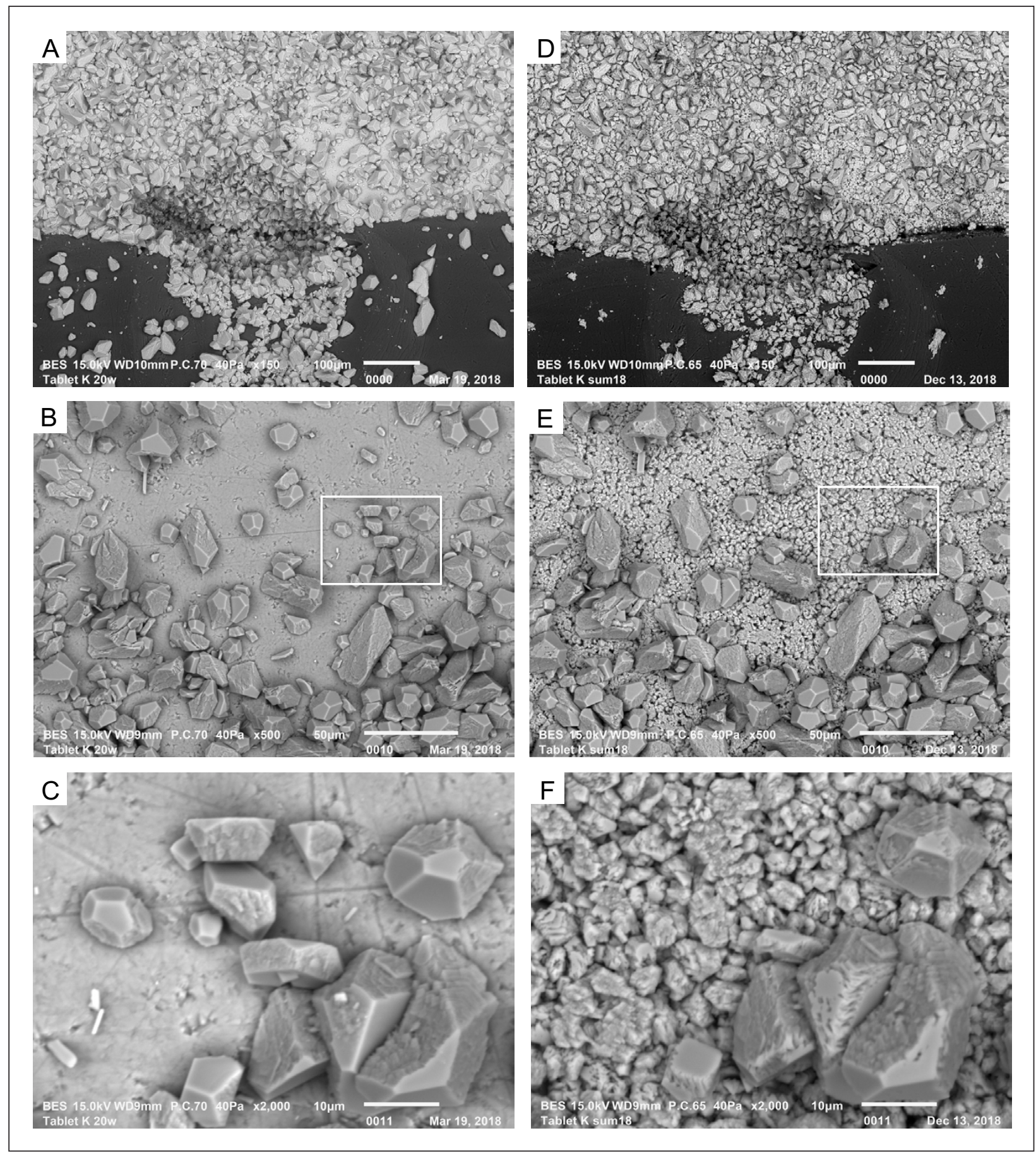

Figure 7: SEM images of Tablet $K$ showing seasonally controlled precipitation and dissolution on stalagmite RD4. A-C) Tablet K after 20 weeks in the cave during winter; calcite crystal growth is clearly seen to have happened on the flat tablet zero surface. D-F) Tablet K after 20 weeks in the cave in winter followed by 28 weeks in the cave during summer; the same crystals that were precipitated in winter (shown in $A-C)$ now show evidence of dissolution, along with the tablet zero surface. A and D (scale bars $100 \mu m$ ) show the rock-resin interface with the marking line visible, which has been infilled with calcite crystals. B and E show an example of an area $3 \mathrm{~mm}$ from the rock-resin interface (scale bar $50 \mu \mathrm{m}$ ), while $C$ and F are higher magnification images (scale bar $10 \mu \mathrm{m}$ ) of the same selected area. Calcite crystals were clearly precipitated during winter and then partially dissolved in summer. The original tablet surface was strongly affected by dissolution during summer and the polishing scratch marks were completely obliterated. 


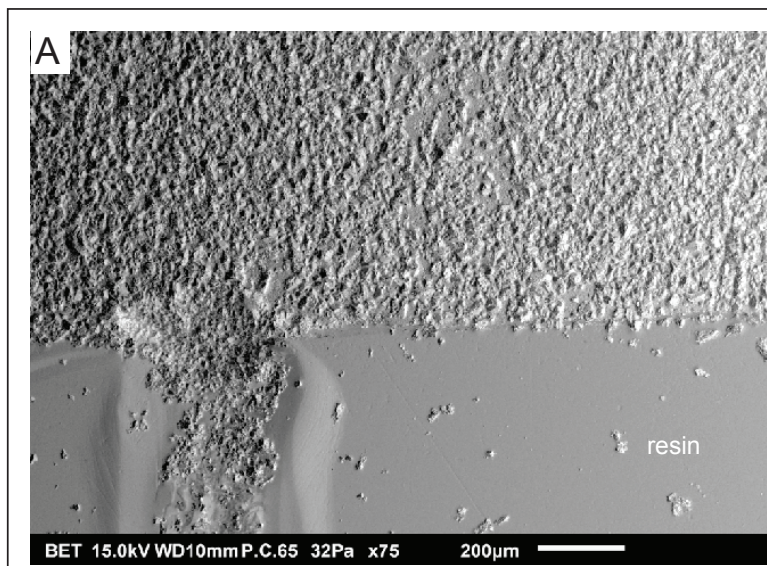

B

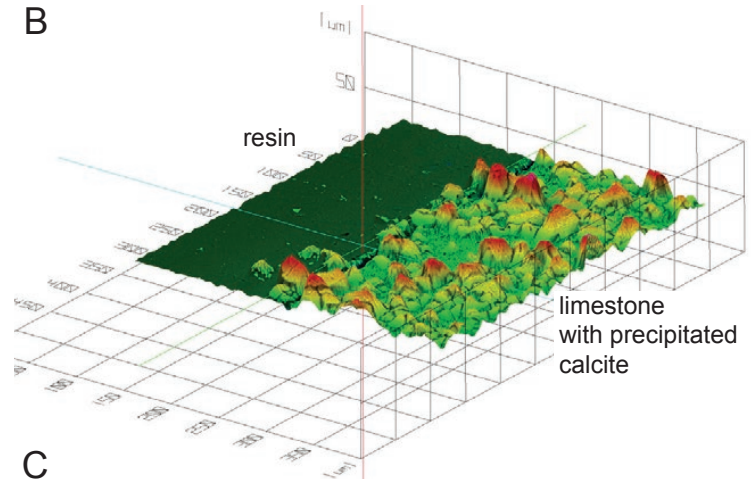

C

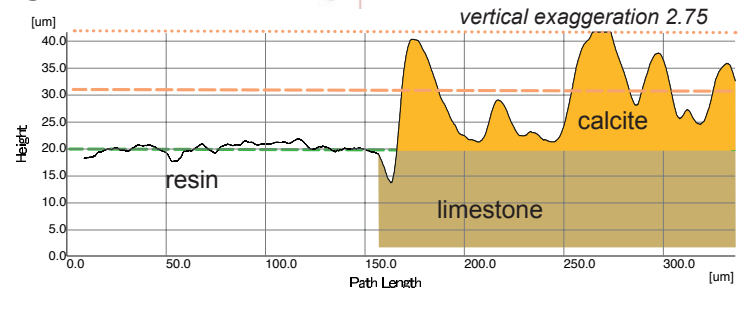

Figure 8: SEM image, 3D topographic model and cross-section used for quantitative analysis of limestone precipitation at Site 2 (RD4 stalagmite). A) BET image of tablet $K$ showing the resin and the limestone with precipitated calcite crystals. Note the marking line on the resin with some precipitated calcite within the groove (lower left part). B) 3D topographic reconstruction of the border between the resin (dark green) and the calcite (green to red) after 20 weeks in the cave in winter followed by 28 weeks in the cave in summer. C) Cross-section, perpendicular to the resin-limestone border, showing the resin level (green dashed line), maximum (dotted orange line) and mean (dashed orange line) height of precipitated calcite crystals.
2018) (Johnston et al., 2019). After 20 weeks in winter (Figure 7A-C), calcite crystals have precipitated onto the tablet surface. A high abundance of relatively large calcite crystals is seen on the tablet surface in Figure 7A, which are also present on the resin and infilling the marking line. The calcite crystals are rhombohedral and range in size up to approximately $50 \mu \mathrm{m}$. The original zero surface of the limestone can be seen clearly in the spaces between precipitated crystals (Figure 7B, C). The tablet, including the calcite that had been formed over the winter period, was placed back in the cave for the summer period. After the summer period, we see a very different process had occurred on the tablet surface. Instead of calcite precipitation, we see evidence of calcite dissolution (Figure 7D-F). At the marking line (Figure 7D), there were fewer calcite crystals present on the resin. The original surface of the tablet now shows a mosaic pattern with dissolution along the crystal margins, however, the calcite crystals that were precipitated during winter still mostly remain on the surface. This can be seen more clearly in the higher magnification images (Figure 7C, F) that were taken in exactly the same position as we had previously analysed. Comparing Figure 7C with 7F, we can see that it was not just the original tablet surface that was affected by the summer dissolution, but also the new crystals that were precipitated during winter were now etched along the stepped crystal margins, although to a much lesser extent, while some other entire crystals are clearly missing. The polishing scratch marks were also completely obliterated by the dissolution.

The stereoscopic 3D reconstruction (Figure 8), shows that, overall, there has been net precipitation, implying that the stalagmite is actively forming. Analysis of multiple profiles across the resin-limestone border showed that calcite crystals grew up to $25 \mu \mathrm{m}$ above the resin level (Figure $8 \mathrm{~B}$ ). The difference between the resin zero surface and the mean thickness of the precipitated calcite layer measured in the cross-section in Figure $8 \mathrm{C}$ is $11.5 \mu \mathrm{m}$. Considering that the tablet was placed in the cave for almost a complete year, this amount of precipitation would correspond to a precipitation rate of

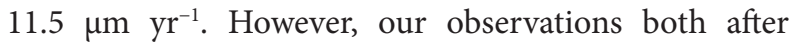
the winter (low $\mathrm{CO}_{2}$ ) and summer (high $\mathrm{CO}_{2}$ ) seasons showed that the precipitation processes occurred only during the winter. 


\section{DISCUSSION}

We have demonstrated that the method proposed here, using a zero surface and a system of marking lines, successfully relocated the imaging points on a carbonate tablet, permitting a robust visual identification of carbonate dissolution/precipitation that occurred during field exposure. Additionally, the zero surface that also includes an insoluble component permitted a quantitative analysis of the rates of calcite dissolution and/or precipitation. We now discuss the key features that are required for successful imaging and quantitative analysis, and then outline some possible limitations of the method. These are evaluated using a SWOT analysis (Table 1).

Firstly, for a successful experiment, the rock used to make the tablets must have a homogeneous crystal size and composition to avoid strong variations in the dissolution/precipitation processes due to textural or compositional differences. This permits a better comparison between different field sampling sites. Moreover, using a homogeneous rock allows comparison of various points on the same tablet, which may be important if the location of dissolution/precipitation varies within the size (mm- to $\mathrm{cm}$-scale) of the tablet; for example, to investigate dissolution/precipitation gradients between that occurring in a cave pool, to that at the water-air interface, to that in the cave air, or alternatively, to assess calcite precipitation on a stalagmite directly below a drip point to that a few centimetres away.

Secondly, the method of embedding in resin allowed the formation of an insoluble component at the same zero surface as the tablet rock, enabling the comparison in height difference, permitting the eventual quantitative calculation of dissolution rates. Moreover, the insoluble nature of the resin allowed the physical marking lines to be made that would not be affected by the field exposure, to be used as a future reference to find the same observation points under the SEM.

Thirdly, the polishing used to create the zero surface allows the 3D SEM analysis to calculate dissolution rates, while also permitting the identification of very small differences in the rock surface after limited periods of field exposure. In addition, an unexpected advantage of the polishing method used here, was the presence of scratches on the tablet surface. These polishing scratches have been used as helpful reference details when visualising the exact position after field exposure and their widening/deepening or complete obliteration could provide additional evidence for the amount of dissolution that had occurred.

Fourthly, the essential feature of our method, to find the exact location on the tablet for the before and after imaging, was the adaptation of the SEM sample holder. Even a slight offset of the tablet would cause complexities to the ability to relocate the same position on the tablet, particularly during the second stage of the relocating process that uses the software's coordinate system to move a certain distance. Moreover, the SEM image obtained after field exposure may be rotated compared with the before image, causing an aesthetically displeasing result.

A fifth advantage of our method is the possibility to observe the surface of the rock repeated times, due to the minimum preparation of the tablet surface required for SEM observation. The samples are simply air dried and they do not need to be washed or desiccated, as required with weight-loss tablets methods. This can be very useful, for instance, when microbial activity is involved in the studied setting, since we can make observations at high magnification to identify individual microbes or biofilms that can contribute to dissolution or precipitation (Johnston et al., 2021). Additionally, with SEM observation of un-washed tablets, we can identify the presence of detrital material, such as clays or weathered carbonate grains, and distinguish them from newly precipitated crystals and assess their influence on dissolution and precipitation processes.

Overall, these advantages show that our method could be successfully used to assess ongoing carbonate dissolution and precipitation processes for diverse applications, including the preservation of cultural artefacts, assessing the lifetime of construction materials and associated engineering problems, geological processes (e.g., slope stability, karst processes), and additionally, to identify microbially-mediated dissolution/precipitation for possible bioremediation applications.

However, our method does have limitations that need to be assessed based on the individual needs of such experiments. Importantly, the method involves the modification of the rock properties due to polishing, which mechanically affects the crystal forms, exposing cut surfaces rather than the original flat crystal faces. This could potentially increase or decrease the initial rate of dissolution. For example, both Moses (1996) and Plan (2005) found that polishing tablets retarded weathering and reduced the rate of dissolution compared with unpolished tablets in various field locations. This may be the case when the polished surface enhances run-off of water from the tablet, such as when measuring dissolution by rainfall or below a cave drip point. Based on our observations that natural crystal faces in pores (Figure 5B) and on newly formed calcite (Figure 7F) seem to be less dissolved than the polished tablet surface, we hypothesise that polishing may enhance the dissolution rate in the 
short-term because it exposes crystals cut in directions that do not correspond to their natural cleavage planes that are likely more resistant than the unnatural cut surfaces (Levenson \& Emmanuel, 2013). However, dissolution experiments in polished calcite surfaces (Bisschop et al., 2006; Smith et al., 2013; Sulley Addo, 2013) have shown a negligible influence of crystal orientation and applied stress on long-term dissolution rates. A possible solution could be to use a cut but unpolished tablet, but risking an uneven zero surface that could compromise the quantification of dissolution or precipitation rates. Alternatively, the tablets could be to first exposed to a weak acid to etch the surface, creating a more natural surface (Prelovšek, 2009), and then take the before im-

Table 1: SWOT (Strengths, Weaknesses, Opportunities, Threats) analysis of our method to quantify rates of carbonate dissolution and precipitation using rock tablets observed before and after with SEM.

\begin{tabular}{|c|c|}
\hline STRENGTHS & WEAKNESSES \\
\hline $\begin{array}{l}\text { Successful relocation of points on tablet enables before } \\
\text { and after imaging of the exact same location. } \\
\text { Permits the processes of carbonate dissolution and pre- } \\
\text { cipitation to be distinguished. } \\
\text { Permits a quantitative estimate of the dissolution/pre- } \\
\text { cipitation rate by using an insoluble material to create a } \\
\text { zero surface. } \\
\text { Enables measurements to be made after only a short } \\
\text { exposure time in the field. } \\
\text { The SEM technique can produce a 3D image of the rock } \\
\text { surface. } \\
\text { Polishing scratches may provide another form of refer- } \\
\text { ence points on the tablet rock surface. } \\
\text { Adaption of the SEM holder permits the tablet to be } \\
\text { placed in the same position before and after field expo- } \\
\text { sure. } \\
\text { Minimal tablet preparation for SEM observation allows } \\
\text { the tablet to be re-placed in the field and analysed nu- } \\
\text { merous times. } \\
\text { Presence of detrital material or microbes/biofilms can } \\
\text { also be assessed. } \\
\text { Uses built-in software on the SEM. }\end{array}$ & $\begin{array}{l}\text { Requires considerable time on the SEM if a number of } \\
\text { tablets are used in the experiment. } \\
\text { To avoid erroneous estimates of dissolution rates caused } \\
\text { by textural and/or compositional variations, a homoge- } \\
\text { neous tablet rock is required, which may be different than } \\
\text { the host-rock of interest. } \\
\text { Under extreme conditions, the rock cuboid may fall out of } \\
\text { the insoluble resin casing. } \\
\text { Requires the use of an SEM holder that is dedicated to the } \\
\text { experiment. } \\
\text { The built-in SEM software does not include the facilities } \\
\text { for in-depth topographic analyses. }\end{array}$ \\
\hline OPPORTUNITIES & THREATS \\
\hline $\begin{array}{l}\text { The method could be tested on various rock types, in- } \\
\text { cluding non-carbonate rocks, to assess weathering rates. } \\
\text { The method could be used in various settings, including } \\
\text { geological, construction materials, aiding preservation of } \\
\text { cultural objects and bioremediation. } \\
\text { Tablets could be placed in various locations along a flow- } \\
\text { path to assess at which point the majority of dissolution/ } \\
\text { precipitation is occurring. } \\
\text { Tablets could be used in conjunction with other methods } \\
\text { for assessing dissolution rates (e.g., weight-loss pills, } \\
\text { micro-erosion meters). } \\
\text { For advanced analyses, the SEM microtopography data } \\
\text { could be exported to more sophisticated software for 3D } \\
\text { mapping. } \\
\text { The tablet construction and methods could be easily } \\
\text { modified to suit the research aims and field environment. } \\
\text { Can be used to assess changing rates of dissolution/pre- } \\
\text { cipitation, such as on a seasonal basis. } \\
\text { Possibility to study spatial variability of dissolution/pre- } \\
\text { cipitation on mm- to cm-scales. }\end{array}$ & $\begin{array}{l}\text { Polishing the tablets modifies the surface properties, and } \\
\text { thus, may change the dissolution/precipitation rates away } \\
\text { from the natural state. } \\
\text { Polishing scratches may change rates of dissolution/pre- } \\
\text { cipitation on a micro-scale. } \\
\text { Limited permeability of the rock due to the resin embed- } \\
\text { ding could affect the results in long-term studies. } \\
\text { As a common problem with short-term tablet experi- } \\
\text { ments, extrapolation of results to provide estimates of } \\
\text { dissolution/precipitation rates on long timescales is dubi- } \\
\text { ous. }\end{array}$ \\
\hline
\end{tabular}


ages and carry out 3D evaluations of the acid-dissolved surface. However, after the field experiment, this could cause difficulties in the visual comparisons, unless large amounts of dissolution had occurred. Moreover, having two complicated surfaces would compound the uncertainties in the 3D SEM stereoscopic reconstructions used to quantify surface-height differences of the before and after tablet surfaces.

Another limitation of our method is for its use for quantifying long-term dissolution rates. Extrapolation of the rates of dissolution from a small $(\mu \mathrm{m})$ spatial scale and a short (weeks/months) temporal scale to a long (years/thousands of years) and large ( $\mathrm{cm}$ - to $\mathrm{m}$-scale dissolution) would be speculative. Extrapolation of results is only recommended with long exposure times and, possibly, used in conjunction with other methods, such as weight-loss tablets or micro-erosion meters. Accordingly, we have presented a method that was apt to our needs but may require modifications depending on the specific field conditions and the overall aim of future research.

The basic built-in SEM software used in this study has shown its benefits but also several limitations. The major advantage is the simplicity of the 3D SEM interface and its connection to the image acquisition module of the SEM. For the stereoscopic reconstructions, the 3D software directly uses the metadata stored in .txt files associated with SEM images, thus preserving the scale and units used in all further calculations (e.g., in plotting cross-sections). The software, however, does not enable more complex topographic analysis, for example, step height estimation based on surface parameters calculated from larger areal segments of compared surfaces or volumetric estimates. Advanced analysis can be performed on DEM files, exported to more sophisticated 3D mapping and modelling software (e.g., Surfer ${ }^{\diamond}$ or Smile View Map ${ }^{\mathrm{m}}$ ) but with considerably more time-consuming operations.

\section{CONCLUSIONS}

We have presented a method to identify and quantify the rates of carbonate dissolution or precipitation on a micro-scale that can be used to monitor these processes on short time-scales (e.g., weeks to months). Our methods require the preparation of tablets composed of both a very homogeneous carbonate rock and an insoluble component, such as resin, which are polished together to form a "zero surface". Images were obtained by SEM both before and after the field experiment, which was carried out here in a cave. A system of marking lines on the insoluble material allowed relocation of the exact points that were observed before exposure to the field environment. The comparison between the images obtained before with those after the field exposure allowed the visual identification of which process, dissolution or precipitation, was occurring. Moreover, the comparison between the insoluble resin zero surface and the modified carbonate surface provided the opportunity to quantify the amount of dissolution or precipitation that had occurred during exposure to the field conditions via a 3D SEM stereoscopic reconstruction. We observed tablets from two sites in Postojna Cave, Slovenia, one of which was dissolving carbonate, while the other site showed evidence of seasonally dependent dissolution and precipitation. Using the methods described here, we were able to determine which process, carbonate dissolution or precipitation, was occurring at our cave sites on a micro-scale and over a short field exposure period.

\section{ACKNOWLEDGEMENTS}

The authors acknowledge the projects J1-9185: “Terrestrial carbonates: mineral products of geobiological processes in the critical zone" and L6-9397: "Methodology for monitoring the sustainable use of karst show caves with automatic measurements - role model - Postojna cave" that are financially supported by the Slovenian Research Agency (ARRS). Thanks to Mineral d.o.o, Lesno Brdo Quarry, for providing the limestone samples. Kata Cvetko Barić assisted in the preparation of the tablets.
We thank Franci Gabrovšek (IZRK, ZRC SAZU) for enthusiastically introducing us to the question of how the intriguing dissolution cups are forming in Postojna Cave and Lovel Kukuljan (IZRK, ZRC SAZU) for assistance in the field and with tablet preparation. Postojna Cave Management kindly permitted access to the cave for research purposes. We are extremely grateful for the helpful comments from Lukas Plan and one anonymous reviewer. 


\section{REFERENCES}

Bierman, P., Steg, E.J., 1996. Estimating rates of denudation using cosmogenic isotope abundances in sediment. Earth Surface Processes and Landforms, 21: 125-139. https://doi.org/10.1002/(SICI)10969837(199602)21:2<125::AID-ESP511>3.0.CO;2-8

Bisschop, J., Dysthe, D.K., Putnis, C.V., Jamtveit, B., 2006. In situ AFM study of the dissolution and recrystallization behaviour of polished and stressed calcite surfaces. Geochimica et Cosmochimica Acta, 70: 1728-1738. https://doi.org/10.1016/j. gca.2005.12.013

Covington, M.D., Prelovšek, M., Gabrovšek, F., 2013. Influence of $\mathrm{CO}_{2}$ dynamics on the longitudinal variation of incision rates in soluble bedrock channels: Feedback mechanisms. Geomorphology, 186: 8595. https://doi.org/10.1016/j.geomorph.2012.12.025

De Muynck, W., De Belie, N., Verstraete, W., 2010. Microbial carbonate precipitation in construction materials: A review. Ecological Engineering, 36: 118136. https://doi.org/10.1016/j.ecoleng.2009.02.006

Ford, D.C., Williams, P.W., 2007. Karst Hydrogeology and Geomorphology. John Wiley \& Sons, Chichester, 562 pp.

Fornós, J.J., Gómez-Pujol, L., Cifre, J., Hierro, F., 2011. First steps in limestone weathering and erosion: an Atomic Force Microscopy (AFM) and Scanning Electron Microscopy (SEM) approach. Acta Carsologica, 40(2): 275-282. https://doi.org/10.3986/ ac.v40i2.12

Furlani, S., Cucchi, F., Forti, F., Rossi, A., 2009. Comparison between coastal and inland Karst limestone lowering rates in the northeastern Adriatic Region (Italy and Croatia). Geomorphology, 104(1): 73-81. https://doi.org/10.1016/j.geomorph.2008.05.015

Gabrovšek, F., 2009. On concepts and methods for the estimation of dissolutional denudation rates in karst areas. Geomorphology, 106(1): 9-14. https://doi. org/10.1016/j.geomorph.2008.09.008

Gams, I., 1981. Comparative research of limestone solution by means of standard tablets. In: Proceedings of the $8^{\text {th }}$ International Congress of Speleology, International Union of Speleology. Bowling Green, Kentucky, USA, July 1981, pp. 273-275.

Goudie, A.S., 2016. Quantification of rock control in geomorphology. Earth-Science Reviews, 159: 374-387. https://doi.org/10.1016/j.earscirev.2016.06.012

Gunn, J., 1981. Limestone solution rates and processes in the Waitomo district, New Zealand. Earth Surface Processes and Landforms, 6: 427-445. https://doi. org/10.1002/esp.3290060504
Häuselmann, P., 2008. Surface corrosion of an Alpine karren field: recent measures at Innerbergli (Siebenhengste, Switzerland). International Journal of Speleology, 37(2): 107-111. http://dx.doi. org/10.5038/1827-806X.37.2.3

High, C., Hanna, G.K., 1970. A method for the direct measurement of erosion of rock surfaces. British Geomorphological Research Group Technical Bulletin, 5: $24 \mathrm{pp}$.

Johnston, V.E., Martín-Pérez, A., Košir, A., Gabrovšek, F., Kukuljan, L., 2019. Estimation of calcite dissolution and precipitation rates in a $\mathrm{CO}_{2}$-rich cave chamber using limestone tablets and SEM imaging techniques. In: Bathurst Meeting 2019, $16^{\text {th }}$ International Meeting of Carbonate Sedimentologists, Mallorca, Spain, July 2019, pp. 64.

Johnston, V.E., Martín-Pérez, A., Skok, S., Mulec, J., 2021. Microbially-mediated carbonate dissolution and precipitation; towards a protocol for ex-situ, caveanalogue cultivation experiments. International Journal of Speleology, 50(2): 137-155. https://doi. org/10.5038/1827-806X.50.2.2372

Krklec, K., Domínguez-Villar, D., Carrasco, R.M., Pedraza, J., 2016. Current denudation rates in dolostone karst from central Spain: Implications for the formation of unroofed caves. Geomorphology, 264: 1-11. https://doi.org/10.1016/j.geomorph.2016.04.007

Krklec, K., Domínguez-Villar, D., Perica, D., 2021. Use of rock tablet method to measure rock weathering and landscape denudation. Earth-Science Reviews, 212: 103449. https://doi.org/10.1016/j.earscirev.2020.103449

Kukuljan, L., Gabrovšek, F., Covington, M.D., Johnston, V.E., 2021a. $\mathrm{CO}_{2}$ dynamics and heterogeneity in a cave atmosphere: role of ventilation patterns and airflow pathways. Theoretical and Applied Climatology 146: 91-109. https://doi.org/10.1007/s00704021-03722-w

Kukuljan, L., Gabrovšek, F., Johnston, V.E., 2021b. Lowcalcium cave dripwaters in a high $\mathrm{CO}_{2}$ environment: Formation and development of corrosion cups in Postojna Cave, Slovenia. Water, 13: 3184. https:// doi.org/10.3390/w13223184

Levenson, Y., Emmanuel, S., 2013. Pore-scale heterogeneous reaction rates on a dissolving limestone surface. Geochimica et Cosmochimica Acta, 119: 188-197. https://doi.org/10.1016/j.gca.2013.05.024

Levenson, Y., Ryb, U., Emmanuel, S., 2017. Comparison of field and laboratory weathering rates in carbonate rocks from an Eastern Mediterranean 
drainage basin. Earth and Planetary Science Letters, 465: 176-183. https://doi.org/10.1016/j. epsl.2017.02.031

Moses, C.A., 1996. Methods for investigating stone decay in polluted and 'clean' environments, Northern Ireland. In: Smith B.J., Warke, P.A. (Eds.), Processes of Urban Stone Decay. Donhead Publishing, London, UK, 212-227 pp.

Moses, C., Robinson, D., Barlow, J., 2014. Methods for measuring rock surface weathering and erosion: A critical review. Earth-Science Reviews, 135: 141161. https://doi.org/10.1016/j.earscirev.2014.04.006

Plan, L., 2005. Factors controlling carbonate dissolution rates quantified in a field test in the Austrian Alps. Geomorphology, 68(3): 201-212. https://doi. org/10.1016/j.geomorph.2004.11.014

Prelovšek, M., 2009. Present-day speleogenetic processes, factors and features in the epiphreatic zone $[\mathrm{PhD}$ thesis]. University of Nova Gorica, $297 \mathrm{pp}$.

Smith, M.E., Knauss, K.G., Higgins, S.R., 2013. Effects of crystal orientation on the dissolution of calcite by chemical and microscopic analysis. Chemical Geology, 360-361: 10-21. http://dx.doi.org/10.1016/j. chemgeo.2013.09.015

Stephenson, W.J., Finlayson, B.L., 2009. Measuring erosion with the micro-erosion meter-Contributions to understanding landform evolution. Earth-Science
Reviews, 95(1): 53-62. https://doi.org/10.1016/j. earscirev.2009.03.006

Stone, J., Evans, J., Fifield, L., Allan, G., Cresswell, R., 1998. Cosmogenic chlorine-36 production in calcite by muons. Geochimica et Cosmochimica Acta, 62: 433-454. https://doi.org/10.1016/S00167037(97)00369-4

Sulley Addo, T., 2013. Effect of Sample Miscut on Dissolution Kinetics of Calcite (104) Cleavage Surfaces [MS thesis]. Wright State University, $88 \mathrm{pp}$.

Trudgill, S.T., High, C.J., Hanna, F.K., 1981. Improvements to the Micro-erosion meter. British Geomorphological Research Group Technical Bulletin, 29: 3-17.

White, J.H., Domínguez-Villar, D., Hartland, A., 2021. Condensation corrosion alters the oxygen and carbon isotope ratios of speleothem and limestone surfaces. Results in Geochemistry, 2: 100008. https:// doi.org/10.1016/j.ringeo.2021.100008

Xu, S., Liu, C-Q., Freeman, S., Lang, Y-C., Schnabel, C., Tu, C-L., Wilcken, K., Zhao, Z-Q., 2013. In-situ cosmogenic ${ }^{36} \mathrm{Cl}$ denudation rates of carbonates in Guizhou karst area. Chinese Science Bulletin, 58: 2473-2479. https://doi.org/10.1007/s11434-013$5756-8$ 